\title{
ROLE OF BACTERIAL ADHESION IN THE PATHOGENESIS OF CHOLERA
}

\author{
D. S. Chitnis, K. D. Sharma And R. S. Kamat \\ Department of Clinical Pathology, Haffkine Institute, Parel, Bombay 400 012, India
}

\begin{abstract}
Summary. In studies with the adult-rabbit ileal-loop model, antibodies to the lipopolysaccharide somatic-antigen component of Vibrio cholerae gave passive protection against challenge with live $V$. cholerae. The antisomatic antibodies had no effect on bacterial proliferation and toxin production either in vivo or in vitro; after challenge, antibody-protected and non-protected rabbit ileal loops developed almost identical amounts of cholera toxin and numbers of $V$. cholerae. The protection could be correlated only with a 10-15-fold reduction in the number of $V$. cholerae adherent to the mucous membrane of the antibody-protected loops. The amount of cholera toxin in the two sets of loops ranged from 1600 to 3200 units. In contrast, when biologically active cholera toxin was prepared in vitro, the amount required to induce ileal-loop secretion was very large (25600 units). These findings indicate that toxin production by adherent vibrios on the surface of the mucous membrane is an important factor in the pathogenesis of cholera.
\end{abstract}

\section{INTRODUCTION}

The role of antibacterial immunity in protection against Vibrio cholerae remains far from clear. Because of the failure of the conventional cholera vaccines consisting of killed $V$. cholerae cells to offer sustained protection, antibacterial immunity has been considered ineffective. However, several field trials with killed bacterial vaccines have shown that antibacterial immunity does offer protection though of limited duration (Joo', 1974). Antibacterial antibodies in the absence of complement have been shown to offer passive protection in studies with closed adult-rabbit ileal loops (Schrank and Verwey, 1976; Holmgren and Svennerholm, 1977). Similarly, rabbits immunised with killed bacterial vaccines have been significantly protected against subsequent challenge with live $V$. cholerae in closed ileal loops (Holmgren and Svennerholm, 1977; Bhattacharjee and Srivastava, 1979). In this report, we propose to show that antibacterial antibodies offer protection through prevention of bacterial adhesion to the mucous membrane, and we attempt to clarify the role of bacterial adhesion in the pathogenesis of cholera. 


\section{MATERIALS AND METHODS}

Bacterial strains

Lyophilised strains of the following were maintained at $4{ }^{\circ} \mathrm{C}$ and revived on nutrient agar before use: $V$. cholerae 569B Inaba, a feebly motile but highly toxigenic strain; two strains of wild $V$. cholerae Inaba isolated from cases of cholera which were enterotoxigenic and exhibited active darting motility; two toxigenic, actively motile NAG vibrios, isolated from clinical cases of diarrhoea. The NAG vibrios share flagellar antigens with the classical vibrios but have different somatic antigens (Buchanan and Gibbons, 1974).

\section{Antisera}

Antisomatic (antilipolysaccharide) antiserum (anti-LPS) was raised in rabbits by immunisation with a suspension of boiled cells of $V$. cholerae strain 569B Inaba. Antiserum to live $V$. cholerae (anti-live cholera antiserum) was raised in rabbits by immunisation with a suspension of live $V$. cholerae strain 569B Inaba. A bacterial suspension containing either boiled or live $10^{9}$ vibrios $/ \mathrm{ml}$ was injected intravenously in $0.5,1 \cdot 0,1 \cdot 5$ and 2.0-ml amounts at intervals of 3-4 days. Rabbits were bled 1 week after the last injection. Anti-live cholera absorbed antiserum was anti-live strain 569B Inaba antiserum absorbed with washed and boiled cells of strain 569B Inaba as described by Edwards and Ewing (1972) to remove all anti-LPS activity.

Assay of test antisera. Bacterial agglutination titre was determined with a suspension of live $V$. cholerae strain 569B Inaba as described by De et al. (1958). Anti-LPS was determined by microtitre passive haemagglutination of sheep red cells sensitised with $V$. cholerae strain 569B Inaba LPS prepared by Westphal's method (Kwapinski, 1972). Anti-flagellar antibody was determined by microtitre passive haemagglutination of sheep red cells sensitised with crude flagellar antigen prepared as described by Yancey, Willis and Berry (1979).

\section{Adult-rabbit ileal-loop technique for passive protection studies}

The technique described by De and Chatterje (1953) was used. In-vivo loops of proximal ileum were made. Each loop, $10 \mathrm{~cm}$ long, received the appropriate test antiserum $30 \mathrm{~min}$ before challenge with an optimal dose of live vibrios equivalent to 10 Effective Concentration 50 (EC50) doses. An EC50 dose is the minimum number of organisms capable of inducing $50 \%$ of maximum fluid secretion. The challenge doses used for various strains were: $V$. cholerae strain 569B Inaba, $10^{5}$ cells; $V$. cholerae wild Inaba (1), $2 \times 10^{6}$ cells; $V$. cholerae wild Inaba (2), $8 \times 10^{5}$ cells; wild NAG-vibrio I, $7 \times 10^{6}$ cells; and Wild NAG-vibrio II, $2 \times 10^{6}$ cells.

\section{Assay of cholera toxin}

The cutaneous vascular permeability method of Craig (1965) was used; $0 \cdot 1-\mathrm{ml}$ volumes of dilutions of test samples were injected into the depilated skin of adult rabbits. A zone of erythema and oedema of more than $8 \mathrm{~mm}$ in diameter at $24 \mathrm{~h}$ was considered to be a positive reaction. The total units of cholera toxin in each sample were calculated as follows: total cholera toxin $/ \mathrm{ml}=$ reciprocal of highest dilution giving a positive reaction $\times 10$.

\section{RESULTS}

\section{Passive protection by antibacterial antibodies}

The passive protection afforded by the various test antisera (See Methods) was determined in studies with the adult-rabbit ileal-loop model challenged with live $V$. cholerae. The rabbit antisera raised against boiled or live $V$. cholerae strain 569B Inaba protected up to a titre of 80 against challenge with 
TABLE I

Antisomatic and anti-flagellar antibody in relation to protection of ileal-loops against challenge with $V$. cholerae

\begin{tabular}{l|cccc}
\hline Antiserum & $\begin{array}{c}\text { Bacterial } \\
\text { agglutination } \\
\text { titre }\end{array}$ & $\begin{array}{c}\text { Anti-LPS (Inaba) } \\
\text { titre* }\end{array}$ & $\begin{array}{c}\text { Anti-flagellar } \\
\text { titre† }\end{array}$ & $\begin{array}{c}\text { Protective } \\
\text { titre }\end{array}$ \\
\hline $\begin{array}{c}\text { Anti-live } V . \text { cholerae antiserum } \\
\text { Anti-boiled } V . \text { cholerae antiserum } \\
\quad \text { antisomatic antiserum) }\end{array}$ & 320 & 16000 & 64000 & 80 \\
$\begin{array}{c}\text { Anti-live } V . \text { cholerae antiserum after } \\
\text { absorption with boiled cells }\end{array}$ & 320 & 16000 & 3200 & 80 \\
\hline
\end{tabular}

LPS = lipopolysaccharide; NP= protection not demonstrable.

* Passive haemagglutination titre against sheep red cells sensitised with strain 569B Inaba LPS;

$\dagger$ Passive haemagglutination titre against sheep red cells sensitised with crude flagellar protein of a wild $V$. cholerae Inaba strain;

$\ddagger$ In-vivo ileal loop challenge with $10^{5}$ live cells of $V$. cholerae $569 \mathrm{~B}$ Inaba;

live $V$. cholerae strain 569B Inaba (table I). Because strain 569B Inaba is feebly motile and less pathogenic, similar passive-protection studies were done with wild Inaba strains isolated from patients with cholera. The antisera gave passive protection against wild strains to the same degree (table II). Protection could not be demonstrated with these antisera against challenge with NAG vibrios (table II). When the rabbit anti-live $V$. cholerae antiserum was absorbed with boiled cells of strain 569B Inaba, it lost its protective ability (table II).

The anti-LPS and the antiflagellar titres of the three antibody preparations used in the passive-protection studies are shown in table I.

TABLE II

Passive protection by antisera against challenge of rabbit ileal loops with different vibrios*

\begin{tabular}{l|cc}
\hline & \multicolumn{2}{|c}{ Protective titre of } \\
$\begin{array}{c}\text { Test } \\
\text { vibrio }\end{array}$ & $\begin{array}{c}\text { anti-boiled } \\
V . \text { cholerae } \\
\text { antiserum } \dagger\end{array}$ & $\begin{array}{c}\text { anti-live } V \text {. cholerae } \\
\text { antiserum absorbed } \\
\text { with boiled cells }+\end{array}$ \\
\hline 569B Inaba & 80 & NP \\
Wild Inaba 1 & $40-80$ & NP \\
Wild Inaba 2 & 80 & NP \\
Wild NAG vibrio 1 & NP & NP \\
Wild NAG vibrio 2 & NP & Np \\
\hline
\end{tabular}

$\mathrm{NP}=$ protection not demonstrable.

* In-vivo ileal-loop challenge with 10 EC50 doses; each antiserum was tested in three rabbits.

+ Rabbit antiserum against boiled $V$. cholerae strain 569B Inaba.

$\ddagger$ Rabbit antiserum against live $V$. cholerae strain 569B Inaba absorbed with boiled cells of strain 569B Inaba until free from anti-LPS antibodies. 
Effect of antibacterial antibody on in-vitro proliferation of cholera vibrios and toxin production

Live $V$. cholerae strain 569B Inaba, $1 \cdot 2 \times 10^{6}$ cells, were inoculated into 50 $\mathrm{ml}$ of Syncase medium containing inactivated (decomplemented) normal rabbit serum or antiserum against boiled $V$. cholerae strain 569B Inaba at a final concentration of 1 in 80 . The cultures were shaken at $200 \mathrm{rpm}$ at $37^{\circ} \mathrm{C}$ for $8 \mathrm{~h}$. A sample from each flask was subjected to viable bacterial count and assay of cholera toxin by the cutaneous vascular-permeability method of Craig (1965).

Proliferation and toxin production by $V$. cholerae strain 569B Inaba remained almost the same (table III) in the presence of antiserum or of normal rabbit serum.

\section{Effect of antibacterial antibody on in-vivo adhesion and toxin production}

The adult-rabbit ileal-loop model was used to test the effects of the rabbit antiserum against boiled $V$. cholerae strain 569B Inaba. Alternate loops $10 \cdot 0$ $\mathrm{cm}$ long received either a 1 in 80 dilution of normal rabbit serum or the antiserum directed against boiled cells of strain 569B Inaba. The sera were heated to destroy complement before use. The loops were challenged with $10^{5}$ cells of $V$. cholerae strain 569B Inaba. After $8 \mathrm{~h}$ the loops were opened and the volume of the contents in each was recorded. The contents were subjected to viable vibrio counts and assay of cholera toxin by the cutaneous vascular-permeability method of Craig (1965). The loops were then washed in phosphatebuffered saline, homogenised in a tissue blender and the homogenate was subjected to viable bacterial count, to determine the number of vibrios adherent to the mucous membrane.

The results are shown in table IV. The loops receiving the antiserum were protected, showing $0.5 \mathrm{ml}-1.0 \mathrm{ml}$ of fluid in each loop. Those that received normal rabbit serum showed fluid accumulation of 5.0-7.0 ml/loop. However, the protected and the unprotected loops had virtually the same total number of organisms, i.e., those in the lumen together with those that were

TABLE III

Lack of effect of antisomatic antiserum on in-vitro proliferation of $V$. cholerae strain $569 \mathrm{~B}$ Inaba and toxin production

\begin{tabular}{l|cccc}
\hline Serum & $\begin{array}{c}\text { Initial inoculum } \\
\text { (number of } \\
\text { vibrios/ml) }\end{array}$ & $\begin{array}{c}\text { Final bacterial } \\
\text { count } \\
\text { (cfu/ml after 8 h) }\end{array}$ & $\begin{array}{c}\text { Log increase } \\
\text { in viable } \\
\text { count }\end{array}$ & $\begin{array}{c}\text { Total amount of } \\
\text { exotoxin produced } \\
\text { (skin-sensitising units) }\end{array}$ \\
\hline NRS & $1.2 \times 10^{6}$ & $1.9 \times 10^{8}$ & 3.8808 & 22625 \\
NRS & $1.2 \times 10^{6}$ & $1.4 \times 10^{8}$ & 3.6628 & 11310 \\
ASA & $1.2 \times 10^{6}$ & $1.8 \times 10^{8}$ & 3.8573 & 16000 \\
ASA & $1.2 \times 10^{6}$ & $1.4 \times 10^{8}$ & 3.6628 & 16000 \\
\hline
\end{tabular}

$\mathrm{NRS}=$ decomplemented normal rabbit serum at a dilution of 1 in 80 ; ASA $=$ decomplemented antisomatic antiserum, i.e., rabbit antiserum against boiled cells of $V$. cholerae strain 569B Inaba, at a dilution of 1 in 80 . 
TABLE IV

In-vivo adhesion, proliferation and toxin production of $V$. cholerae strain $569 B$ Inaba in the presence of antisomatic antiserum and normal rabbit serum

\begin{tabular}{|c|c|c|c|c|c|}
\hline \multirow[b]{2}{*}{ Serum } & \multirow{2}{*}{$\begin{array}{c}\text { Total number of } \\
\text { vibrios in } \\
\text { the loop }\end{array}$} & \multicolumn{2}{|c|}{ Number of vibrios } & \multirow{2}{*}{$\begin{array}{l}\text { Total units } \\
\text { of exotoxin } \\
\text { in the lumen }\end{array}$} & \multirow{2}{*}{$\begin{array}{l}\text { Amount of } \\
\text { fluid accumulation } \\
(\mathrm{ml} / \text { loop })\end{array}$} \\
\hline & & free in the lumen & $\begin{array}{l}\text { adherent to the } \\
\text { gut mucosa }\end{array}$ & & \\
\hline & $1.293 \times 10^{9}$ & $1 \cdot 28 \times 10^{9}$ & $1.3 \times 10^{7}$ & 3200 & $7 \cdot 0$ \\
\hline \multirow[t]{4}{*}{ NRS } & $5.675 \times 10^{8}$ & $5.6 \times 10^{8}$ & $7 \cdot 5 \times 10^{6}$ & 1600 & $7 \cdot 6$ \\
\hline & $1.437 \times 10^{9}$ & $1.43 \times 10^{9}$ & $7 \cdot 1 \times 10^{6}$ & 1600 & $5 \cdot 0$ \\
\hline & $7.84 \times 10^{8}$ & $7.65 \times 10^{8}$ & $1.87 \times 10^{7}$ & 1600 & $5 \cdot 0$ \\
\hline & $8.66 \times 10^{8}$ & $8.65 \times 10^{8}$ & $9.65 \times 10^{5}$ & 2262 & $1 \cdot 5$ \\
\hline \multirow[t]{3}{*}{ ASA } & $7.67 \times 10^{8}$ & $7.6 \times 10^{8}$ & $7 \cdot 45 \times 10^{5}$ & 1600 & $1 \cdot 0$ \\
\hline & $1.53 \times 10^{9}$ & $1.53 \times 10^{9}$ & $4.45 \times 10^{5}$ & 1600 & 0.5 \\
\hline & $1.36 \times 10^{9}$ & $1.35 \times 10^{9}$ & $9.55 \times 10^{5}$ & 1600 & 0.0 \\
\hline
\end{tabular}

Abbreviations as in table III.

adherent. Surprisingly, even the total amount of biologically active toxin in the two sets of loops was virtually the same, 1600-3200 units. The protection could be correlated only with 10-15-fold reduction in the number of $V$. cholerae adherent to the mucous membrane of the loops.

\section{Minimum cholera-toxin requirements to induce ileal-loop response}

Crude cholera toxin was prepared in vitro as described by Finkelstein (1969). Adult-rabbit ileal loops were challenged with graded amounts of the crude cholera toxin. At least 25600 skin-sensitising units of in-vitro prepared biologically active cholera toxin were required to induce fluid secretion by the adult-rabbit ileal loop (table V). This is almost 10 times the amount of toxin demonstrable in a loop with fluid accumulation after in-vivo challenge with $10^{5}$ cells of $V$. cholerae strain 569B Inaba.

TABLE V

Ileal-loop response to in-vitro prepared cholera toxin

\begin{tabular}{|c|c|c|}
\hline \multicolumn{2}{|c|}{ Challenge dose of toxin* } & \multirow[b]{2}{*}{$\begin{array}{l}\text { Amount of fluid } \\
\text { accumulation } \\
\text { (ml/loop) }\end{array}$} \\
\hline $\begin{array}{c}\text { Protein } \\
\text { concentration } \\
(\mu \mathrm{g} / \mathrm{ml})\end{array}$ & $\begin{array}{c}\text { Skin-sensitising } \\
\text { doses } / \mathrm{ml}\end{array}$ & \\
\hline 3.0 & 38400 & $11 \cdot 75$ \\
\hline $2 \cdot 5$ & 32000 & $5 \cdot 5$ \\
\hline $2 \cdot 0$ & 25600 & $6 \cdot 0$ \\
\hline 1.25 & 16000 & 0.0 \\
\hline $1 \cdot 0$ & 12800 & $0 \cdot 0$ \\
\hline 0.625 & 8000 & $0 \cdot 0$ \\
\hline
\end{tabular}




\section{Discussion}

The results of the passive-protection studies with the three antisera constitute strong evidence that antibacterial antibodies are responsible for protection, at least when tested in the adult-rabbit ileal-loop model.

It is clear that absorption of anti-live $V$. cholerae antiserum with boiled cells of $V$. cholerae removes the antisomatic antibody and its protective activity, but the absorption does not remove antiflagellar activity. Thus, the protective effect of the anti-live $V$. cholerae antiserum correlates with its anti-LPS and not with its anti-flagellar antibody. Because the somatic antigens of NAG vibrios do not crossreact with the somatic antigens of $V$. cholerae, the lack of protection by the anti-live $V$. cholerae strain 569B Inaba antiserum against challenge with NAG vibrios (table II) is interpreted as additional evidence in support of our hypothesis that the antisomatic antibodies are responsible for the passive protection. These data agree with those reported by Holmgren and Svennerholm (1977) on the role of anti-LPS antibodies in cholera immunity.

One of the factors of prime importance in the pathogenesis of cholera is the motility of the organisms (Yancey, Willis and Berry, 1978). It could be argued that the passive protection offered by the antisomatic antibodies against live challenges with $V$. cholerae in the in-vivo closed ileal loops could be explained by inhibition of motility. If this argument is valid, the antiflagellar antibodies that can inhibit motility effectively should also be capable of offering passive protection. In fact, Yancey et al. (1979) have claimed excellent protection with anti-flagellar antibodies. To resolve these issues we prepared an antiserum against live $V$. cholerae and absorbed it with boiled cells until all anti-LPS activity was lost. This antiserum preparation retained almost as much anti-flagellar activity after absorption as it had before absorption (table I). However, it lost all its ability to offer passive protection along with its loss of anti-LPS activity. Our data and conclusions contradict those of Yancey et al. (1979) who used a similar test system. We must conclude that antisomatic antibodies can afford passive protection in the adult-rabbit ileal-loop model and this is not by virtue of inhibition of motility.

Although the protective effects of antisomatic antibodies have been described by many investigators (Freter, 1970; Holmgren and Svennerholm, 1977; Schrank and Verwey, 1979), the mechanism of protection seems to be far from clear. Local antibacterial antibodies in the gastro-intestinal tract are IgA and complement-mediated killing of the bacteria can be ruled out. Accordingly, in our passive-protection studies, all the sera were used only after complement inactivation. The anti-boiled $V$. cholerae antiserum had no effect on bacterial proliferation and toxin production either in vitro or in vivo. It was surprising to find that both the antibody-protected and the non-protected loops had almost identical amounts of biologically active cholera toxin, 1600-3200 skin-sensitising units, even though the former showed no fluid accumulation whereas the latter accumulated $5-7.5 \mathrm{ml}$ in $8 \mathrm{~h}$. The only difference between the antibody-protected and the non-protected loops was a 10-15-fold reduction in the number of $V$. cholerae adherent to the mucous 
membrane of protected loops. Freter (1970) has also reported inhibition of bacterial adhesion to the mucous membrane in the presence of antisomatic antibodies.

Another important feature of the secretory antibacterial IgA antibodies in the gastro-intestinal tract is that their ability to induce agglutination of the bacteria is very poor. If IgA antibodies play any role in protection, they can do so only by prevention of adhesion of bacteria to the mucous membrane. Accordingly, experiments showing passive protection with antiserum containing IgM and IgG antibodies capable of bacterial agglutination may have no relevance to the in-vivo clinical situation. Indeed the mechanism of the limited protection offered by conventional killed vaccines is not clear. The challenge doses of the various strains of $V$. cholerae used by us $\left(10^{5}-2 \times 10^{6}\right)$ were such that they were non-agglutinable when mixed with varying dilutions of antisera used in the passive-protection studies (data not shown). It might be argued that the proliferation of bacteria during an $8-18-\mathrm{h}$ incubation period in the passive-protection experiments would generate adequate numbers of bacteria that would be agglutinable. This is indeed possible. Nevertheless, the agglutinated bacterial clumps would still be present in the closed loops to generate toxin. Thus the total amount of toxin, as well as the total number of bacteria, in the antibody-protected and the non-protected loops should be the same. Even in the clinical situation, the organisms rendered non-adherent by the local antibacterial antibody are expected to remain in the intestinal lumen for the duration of the emptying time of the small intestine which, in our opinion, is adequate for proliferation and toxin production by the ingested $V$. cholerae.

This suggests an additional, as yet poorly understood, role for bacterial adhesion in the pathogenesis of cholera syndrome. It has been suggested by Schrank and Verwey (1976) and by Bhattacharjee and Srivastava (1979) that the adhesion of $V$. cholerae to the intestinal epithelium may lead to release of toxin in the highest concentration at the correct site. The findings in our study provide strong evidence in favour of this speculation; 1600-3200 skin-sensitising units of cholera toxin were not adequate to induce fluid secretion, when the toxin was produced by vibrios predominantly in the lumen of the ileal loops. However, the same amount of toxin did induce fluid secretion when the number of adherent vibrios in the non-protected loops rose 10-15-fold. We therefore suggest that $V$. cholerae adherent to the mucous membrane can induce fluid secretion by an amount of exotoxin that would be ineffective if produced by the vibrios lying free in the lumen of the intestine. If this hypothesis is correct, a very large amount of in-vitro prepared biologically active cholera toxin would be needed to induce an adult-rabbit ileal-loop response, and this was found to be so. At least 25600 skin-sensitising units of in-vitro prepared cholera toxin were required for inducing an adult-rabbit ileal-loop response. This is at least 8-10 times the amount of exotoxin required to induce fluid secretion when produced by vibrios adherent to the mucous membrane.

Srivastava, Sinha and Srivastava (1980), using a similar experimental system, attempted to titrate toxin in in-vivo closed rabbit-ileal loops chal- 
lenged with different strains of $V$. cholerae with different adhesive potencies. These authors proposed that in-vivo release of toxin depends on adherence of vibrios to the mucous membrane. Our results do not agree with this suggestion and indicate that in in-vivo closed rabbit-ileal loops the total amount of toxin released is the same, whether the organisms are adherent to the mucous membrane or are in the lumen. We suggest that bacterial adherence to the mucous membrane is important, not because it is concerned in the release of toxin, but because the toxin generated is inadequate to induce fluid secretion unless it is released by bacteria adherent to the surface of the mucous membrane. We suggest that this may explain the discrepancy between our data and those of Srivastava et al., (1980). The amount of toxin released by $V$. cholerae in in-vivo closed rabbit-ileal loops is so small that it cannot be detected by the assay of Craig (1965) unless the challenge strain is potently toxigenic such as $V$. cholerae 569B Inaba.

We have presented evidence here to show the importance of toxin release by bacteria on the surface of the mucus membrane. Because the question of bacterial agglutination by the antisera used in our studies cannot be ruled out, the role of antisomatic antibodies in the prevention of bacterial adhesion remains to be resolved. The antisomatic antiserum used in our studies was "operationally" specific against somatic antigens, in the sense that it was not prepared by immunisation of rabbits with pure LPS. Hence, one cannot be certain that the antiserum does not have antibodies against other unidentified vibrio surface antigens. Even if it is assumed that our antisomatic antiserum is very specific, and that it is capable of preventing bacterial adhesion, one cannot rule out an important role for bacterial surface molecules other than the somatic antigens in facilitating adhesion. It is quite possible that the adhesion is brought about by a bacterial surface molecule other than the somatic antigen, but that antibody reacting with the latter sterically hinders the interaction between the former and the mucous membrane. Freter and Jones (1976) have characterised a flagellar protein "adhesin" that is ascribed an important role in the adhesion of $V$. cholerae to the mucous membrane. It is quite possible that our anti-boiled $V$. cholerae antiserum contains antibody activity against adhesion and other known and unknown bacterial surface antigens. These aspects of bacterial adhesion to the mucous membrane have been investigated and are reported in the following paper.

\section{REFERENCES}

BhattacharjeE, J. W. AND SRivastava, B. S. 1979. Adherence of wild-type and mutant strains of Vibrio cholerae to normal and immune intestinal tissue. Bull. Wld Hlth. Org., 57, 123.

Buchanan, R. E. And GibBone, N. E. (eds.), 1974. In Bergey's manual of determinative bacteriology, 8th ed., Williams \& Wilkins, Baltimore, p. 340 .

Craig, J. O. 1965. The effect of cholera stool and culture filtrates on the skin of guinea pigs and rabbits. In Proceedings of a cholera research symposium, edited by O. A. Bushnell, Public health service publication no. 1328, US Govt. printing office, Washington, DC, p. 153-158.

DE, S. N. AND ChatterJe, D. N. 1953. An experimental study of the mechanism of action of Vibrio cholerae on the intestinal mucous membrane. J. Path. Bact., 66, 559.

De, S. N., Lahiri Choudhury, P. K., Ghose, M. L. and Mondal, A. 1958. A study of the 
technique for demonstration of ' $\mathrm{O}$ ' and ' $\mathrm{H}$ ' agglutinins in the serum of cholera patients. Indian J. med. Res., 46, 351.

EDWARDS, P. R. AND EWING, W. H. 1972. Identification of enterobacteriaceae, 3rd ed., Burgess Publishing Co., Minneapolis, p. 178.

Finkelstein, R. A. 1969. Pathogenesis of experimental cholera. Preparation and isolation of choleragen and choleragenoid. J. exp. Med., 130, 185.

FRETER, R. 1970. Mechanism of action of intestinal antibody in experimental cholera. II. Antibody-mediated antibacterial reaction at the mucosal surface. Infect. Immun., 2, 556.

Freter, R. AND Jones, G. W. 1976. Adhesive properties of Vibrio cholerae: nature of the interaction with intact mucosal surfaces. Infect. Immun, 14, 246.

HOLMGREN, J. AND SVENNERHOLM, A. M. 1977. Mechanism of disease and immunity in cholera: a review. J. infect. Dis., 136 suppl, S-105.

Joo', I. 1974. In Cholera, cholera vaccines. edited by D. Barua and W. Burrows, Saunders, Philadelphia, p. 333.

KWAPINSKI, J. 1972. Methodology of immunochemical and immunological research, Wiley Interscience, NY, p. 80.

SCHRANK, G. D. AND VERWEY, W. F. 1976. Distribution of cholera organisms in experimental Vibrio cholerae infection: proposed mechanisms of pathogenesis and antibacterial immunity. Infect. Immun., 13, 195.

Srivastava, R., Sinha, V. B. And Srivastava, B. S. 1980. Events in the pathogenesis of experimental cholera: role of bacterial adherence and multiplication. J. med. Microbiol., 13,1 .

YANCEY, R. J., WILLIS, D. L. AND BERRY, L. J. 1978. Role of motility in experimental cholera in adult rabbits. Infect. Immun., $22,387$.

YanCEY, R. J., Willis, D. L. AND BERRY, L. J. 1979. Flagella-induced immunity against experimental cholera in adult rabbits. Infect. Immun., 25, 220. 